\title{
BIROKRASI DAN KULTUR STRUKTUR RASIONAL-EGALITER:SUMBANGAN AGAMA UNTUK PENGUATAN GOOD GOVERNANCE
}

\author{
Oleh: Ubaidillah Achmad*
}

\section{Abstract}

The role and function of religion recently in the government system seem to have problems because of the believers itself. The fact shows that in the government order that is led by most righteous people, the management indicates various deficiencies, such as inefficiency, authority abuse, collusion, corruption, nepotism, and society's cooptation to support the political party of the regime. Therefore, to improve the order, it cannot be subjected to the religion believers only, without strengthening the good governance. This last statement requires knowledge, attitude, and action of the public service officials. Furthermore, this is a step of improvement of political abuse, including bad performance of bureaucracy. The article tries to highlight the significant role of religious consciousness relevant to the development of good governance. Good governance will be well -implemented, if each takes part actively, together with government, in developing community's understanding on the importance of rational-egalitarians in the government system. It is also required a firmness of moral principles and ethic awareness of all public service officials and society to execute the good governance in the government system.
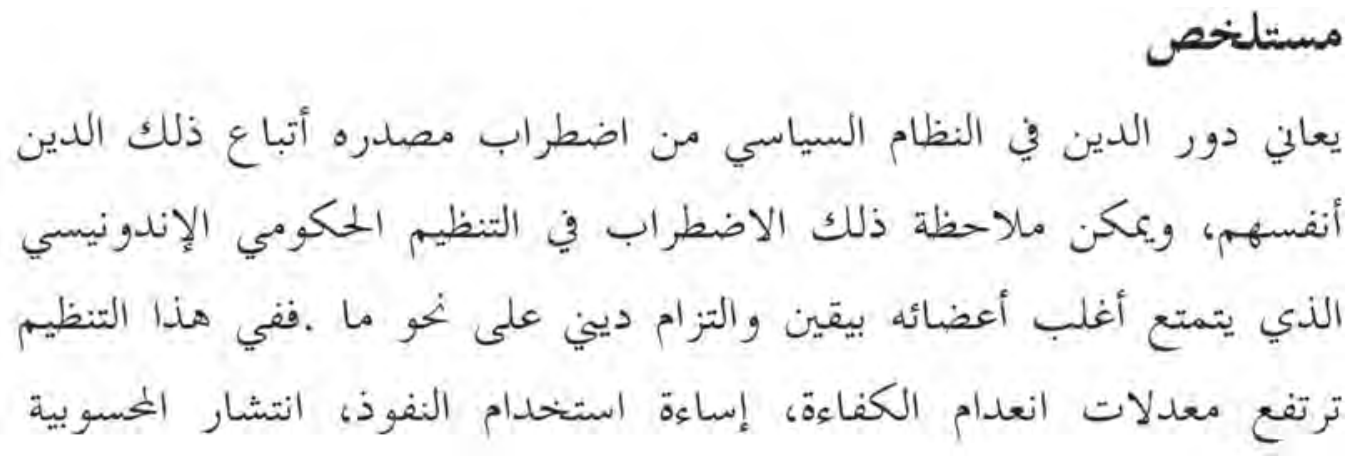

Alumni PPs IAIN Walisongo, bekerja di DEPAG RI.E-mail:almaula1589@yahoo.com 
و الفساد، واستخدام موارد الدولة في دعم الأحزاب السياسية اللحكومية إبان الانتخابات .لذا، وعلى طريق إصلاح ذلك التنظيم، لا ينبغي الاعتماد فقط على مفهوم الأمة المتدينة من غير بذل الجهبا في سبيل تقوية ثنظيمات الحكم الجيد . وفي إطار تقوية الحلكم الجيد يحتاج العاملون بالدولة إلى اكتساب معارف معينة، وبناء ابتاهات دافعية محلدة، إلى جانب خلق سلو كيات إيجابية تتسم بالحياد و العدالة .هذا، وينبغي أن يكوي بحهود دعم اللكم الجيد خطوات إصالاحية بجاه الفساد السياسي .كا فيه تردي مستوى أداء البيروقراطية .وعبر هذه المقالة، يحاول الكاتب إيضاح ما للدين من دور بالغ الدلالة في بناء تنظيمات الحكم الجيد .

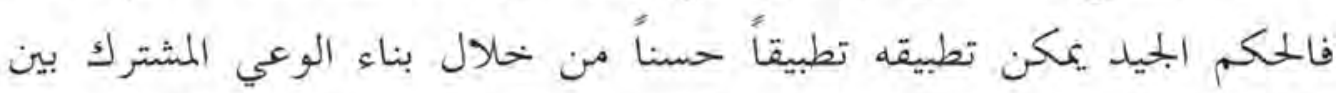

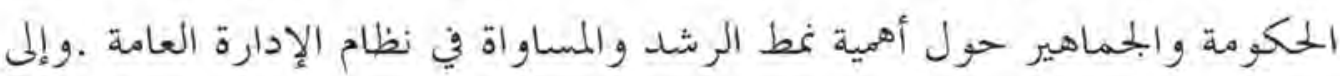
جانب هذا، يُحتاج إلى وضوح الالتزام بسيادة المبادى الأخلافية لدى العاملين العامين بالدولة ولدى الجماهير على حد سواء؛ كل هذا على طريق إرساء دعائم الملكم الجيد بشكل و اقعي في نظام المكىم العام. Keywords: religion, good governance, development, rational-egalitarians

\section{A. Pendahuluan}

Pengalaman pemerintahan di negara berkembang sering disinyalir penuh dengan kecurangan dan KKN. Demikian ini telah mendorong pemerintah, tokoh agama, cendekiawan dan aneka LSM di negara berkembang untuk mencarikan solusi, baik secara preventif maupun kuratif. Problem yang seperti ini muncul, karena adanya proses pengambilan keputusan publik yang tidak sensitif terhadap suarasuara komunitas, proses pengambilan keputusan yang bersifat herarkis, dan menguatnya titik kulminasi yang bermuara pada makna kemiskinan. Problem inilah yang mendasari munculnya berbagai upaya untuk menciptakan pemerintahan yang bersih. Korupsi, kolusi dan nepotisme belum hilang dari praktek oknum-oknum tertentu di lingkungan pemerintahan di negara berkembang. Sebagai conpoh, di Indonesia gerakan reformasi sudah berjalan sembilan tahun, namun masih banyak 
ketidakjelasan tender-tender proyek atau pengurusan izin yang tidak profesional di bidang perbankan dan lainnya. Demikian ini tidak dapat dilepaskan dari pengaruh irasional-hirarkis sistem pemerintahan.

Dalam tulisan ini, penulis hendak memberikan solusi yang bisa diharapkan dapat memberikan nafas baru dalam pemerintahan maupun pembangunan. Dengan demikian, kesadaran keberagamaan menjadi sangat signifikan dan relevan untuk membangun good governance. Dengan kata lain, good governance dapat diterapkan secara efektif, apabila umat beragama turut bersama-sama dengan pemerintah membangun komitmen menegakkannya. Namun demikian, tetap diperlukan pemahaman terkait dengan akar permasalahan; Mengapa muncul pesimisme mendalam terkait dengan menguatnya poor governance? Lalu, bagaimana menguatkan peran agama dalam menciptakan good governance?

\section{B. Wajah Birokrasi: Antara Irasional-Hirarkis dan Rasional-Egaliter}

Wajah birokrasi ini sering juga disalahartikan, sehingga terkesan hanya dikuasai oleh pemimpin birokrasi. Implikasi pengelolaan sistem birokrasi inilah yang kemudian memunculkan sebuah penilaian apakah birokrasi itu dikatagorikan sebagai bentuk tata pemerintahan yang baik atau sebagai bentuk tata pemerintahan yang buruk? Persepsi tentang birokrasi tidak terlepas dari pemahaman seseorang mengenai sebuah bentuk tata pemerintahan. Tata pemerintahan selalu melibatkan yang berkuasa dan yang dikuasai. Dalam tata pemerintahan sering ditemukan dua istilah yang sering disalahpahami: governance dan government.

Governance lebih mengarah pada tindakan dan perilaku yang memerintah. Sedangkan government merupakan kepemilikian otoritas untuk memerintah. Governance memiliki arti mendasar yaitu mengenai pengetahuan, sikap dan tindakan (knowledge, attitude, practice) yang menuntun pada persoalan bagaimana membuat terjadinya suatu perubahan sikap dan perilaku? Jika pemerintah memiliki pengetahuan, sikap dan tindakan yang buruk (bad), maka dapat diubah secara bertahap menjadi baik (good). Karenanya, pengetahuan, sikap dan tindakan merupakan inti atau esensi untuk mewujudkan good governance. Dengan pengetahuan, sikap dan tindakan yang baik, akan melahirkan tata pemerintahan yang baik. Secara otomatis, akan disadari tentang pentingnya menerapkan prinsip yang baik dalam penyelenggaraan pemerintahan. Sistem pemerintahan yang baik mensyaratkan beberapa prinsip seperti tindakan politik; legitimasi mereka yang berkuasa; standar penggunaan kekuasaan; demokratisasi untuk dapat menerima 
kritik dan saran dari masyarakat; kebijakan yang bertujuan untuk memberikan kesempatan kritik dan saran masyarakat; menghindari tuntutan rakyat dan membuka keterlibatan pengawasan politik masyarakat.

Namun demikian, selain dibutuhkan syarat-syarat yang sangat ketat tersebut, dibutuhkan pilar penyangga tegaknya good governance, di antaranya dalam pilar ekonomi, politik, hukum, sosial budaya dan agama. Seluruh faktor ini saling mempengaruhi dan terkait. Kebijakan pemerintah yang cenderung mengejar target ekonomi dan sistem pemerintahan yang sentralistik harus diakui telah menyebabkan perbaikan ke arah pencapaian good governance kurang berkembang secara maksimal. Akibatnya, pilar kehidupan bernegara menjadi lemah dan rapuh. Semua itu tidak lepas dari persoalan rapuhnya moralitas masyarakat, khususnya para penyelenggara pemerintahan. Dalam hal ini, peranan agama memang seharusnya mampu memotivasi dan memberi napas pada semua bidang kehidupan, sehingga muncul sistem ekonomi, politik, hukum dan tatatan sosial budaya yang berkeadilan.

Tetapi dalam realitasnya, agama terlihat kurang berdaya. Prasangka antaretnik, antarkelompok kepentingan, antarentitas keagamaan, dan bahkan antarentitas teritorial cukup mengkhawatirkan kohesi nasional. Kecenderungan saling menuding dan menjatuhkan, terlihat masih saja terus berlanjut. Fenomena itu memberi bukti tingginya tingkat prasangka dan betapa rendahnya kepercayaan antarelemen masyarakat. Begitu rendahnya kepercayaan antarelemen, sehingga muncul illegitimasi atau saling tak percaya. Rakyat tak percaya pada pemerintah, begitu sebaliknya. Sementara kepercayaan tersebut amat diperlukan untuk membangun kesatuan atau kohesi bangsa.

Dengan didasarkan pada kenyataan peradaban manusia (waqi'at al-umran albasyari $^{1}$ ), berlangsungnya sistem pemerintahan dapat dianalisis dengan dua pendekatan, yaitu struktur irasional-hirarkis dan struktur rasional-egaliter. Struktur rasional-egaliter menegaskan, bahwa segala kebijakan birokrasi harus mudah dimengerti (clearly understandable) dan mudah didapatkan (freely available). Sedangkan, struktur irasional-hirarkis, lebih mengutamakan kepentingan penguasa dengan menafikan peran-peran yang dikuasai (the governed). Dampak pemerintahan seperti ini, akan menjadi sebagai penyebab terjadinya ledakan dahsyat yang bukan saja akan menghancurkan negara dan otoritas birokrasi, tetapi juga menghancurkan sistem sosial yang telah membantu menegakkannya. ${ }^{2}$ Fiqr, 1951).

1 Istilah ini penulis ambil dari Abdurrahman Ibn Khaldun, Muqaddimah, (Beirut: Dar al 2 Muhammad A.S. Hikam, Demokrasi dan Civil Society, (Jakarta: LP3ES, 1999), hal. 21. 
Struktur irasional-hirarkis merupakan problem pemerintahan di negara yang sedang berkembang. Secara spesifik, problem dimaksud berupa "the paradox of development administration" . Artinya, adanya sistem administrasi yang efektif belum menjamin keberhasilan pembangunan di negara berkembang, namun sistem administrasi yang terlalu efektif dapat juga menghambat kelangsungan pembangunan. Hal ini dikarenakan kehendak membangun good governance telah menjadi kebiasaan dengan ketergantungan pada birokrasi pemerintah yang sudah terlanjur terpusat pada kekuasaan pemimpin.

The paradox of development administration merupakan problem terbesar yang dihadapi negara berkembang. Contoh, birokrasi Indonesia dinilai termasuk terburuk dan belum mengalami perbaikan berarti yang setelah bergulirnya reformasi 21 Mei 1998. Di tahun 2000, Indonesia memperoleh skor 8,0 atau tak bergerak dari skor 1999, dalam kisaran skor yang dimungkinkan, yakni nol untuk terbaik dan 10 untuk terburuk. Skor 8,0 atau jauh di bawah rata-rata ini diperoleh berdasarkan pengalaman dan persepsi expatriats yang menjadi responden. Masih banyak responden yang menganggap pejabat tinggi pemerintah Indonesia yang memanfaatkan posisi mereka untuk memperkaya diri sendiri dan orang terdekat. ${ }^{4}$

Dengan demikian, perlu adanya pembenahan dan perbaikan sistem pemerintahan yang selama ini berlangsung. Permasalahan yang sesegera membutuhkan pembenahan itu adalah adanya sikap ketergantungan pelaksana yang harus selalu menunggu petunjuk, perintah dan persetujuan dari atasan. Oleh karena itu, setiap pemimpin di lembaga birokrasi pemerintah berkewajiban membebaskan dan mencerahkan problem psikis pelaksananya. Sebab, tidak semua pelaksana memiliki kesadaran kritis. Bentuk feodalisme pelaksana seperti ini justru banyak dimanfaatkan para pemimpin untuk menguatkan hegemoni kekuasaannya. Permasalahan lainnya adalah kualitas pelayanan birokrasi yang dinilai buruk, lama, dan berbelit-belit. Hal ini akan memudahkan masyarakat untuk memberikan penilaian dan membandingkan dengan sistem yang diterapkan di sebuah perusahaan swasta yang selalu memberikan pelayanan interaktif, kompetitif dan cepat.

3 Sofian Effendi, "Revitalisasi Sektor Publik Menghadapi Keterbukaan Ekonomi dan Demokratisasi Politik," dalam Pidato Pengukuhan Jabatan Guru Besar Pada Ilmu Sosial dan Ilmu Politik UGM, (Yogyakarta: UGM Press, 2000), hal. 928.

4 Lihat Masalah Birokrasi di Indonesia, Jurnal Transparansi, Website Masyarakat Transparansi Indonesia, Edisi 18 Maret 2000. 
Masalah Birokrasi di Indonesia, dipahami sebagai suatu yang negatif, menyulitkan dan tidak lancar. Demikian ini karena tidak terlepas dari penyalahgunaan wewenang di lembaga birokrasi itu sendiri. Masih banyak para pemimpin lembaga birokrasi yang memahami lembaganya sebagai lembaga yang penuh kehati-hatian dan segala bentuk kebijakan yang dikeluarkan melalui lembaga ini harus dibahas melalui rapat dan pertemuan gabungan antar para pimpinan. Oleh karenan itulah, lembaga birokrasi diartikan menjadi pemerintahan meja. Dengan kata lain, sebuah pemerintahan itu berjalan dari meja satu ke meja lain. ${ }^{5}$ Demikian ini tidak menutup kemungkinan menjadi penyebab munculnya dampak sampingan yang ada di tiap biro, meja, kamar, departemen, dan lain-lain.

Meskipun birokrasi ini merupakan suatu keniscayaan dalam sebuah sistem pemerintahan, baik pemerintahan tradisional maupun modern, namun keberadaannya bukan berarti mengabaikan upaya perbaikan dan penerapan mutu pelayanan publik. Untuk itu, sebelum membahas bangunan pemerintahan yang baik, perlu melakukan pembenahan terlebih dahulu pada sistem birokrasi pemerintah. Pengertian birokrasi yang secara etimologis berarti meja, keberadaannya dapat dibangun dengan cara yang rasional maupun dengan cara yang irasional. Baik buruknya sistem birokrasi di Indonesia tidak dapat dilepaskan dari pola pembangunan yang akan dikeluarkan oleh pemerintah pusat, yakni birokrasi dan kultur struktur irasional-hirarkis dan struktur rasional-egaliter.

Bentuk birokrasi dan kultur struktur irasional-hirarkis merupakan bentuk pemerintahan yang sering mengabaikan tanggung jawab pelayanan kepada masyarakat. Pola birokrasi seperti ini hanya memberikan pelayanan kepada golongan atas. Proses pelayanan seperti ini tanpa disadari telah membentuk karakter para pejabat menjadi feodalistik. Artinya, orientasi pada atasan makin kuat dan selalu dibarengi dengan ketergantungan sepenuhnya (fully dependent), yang mirip gaya renang katak, ke atas menyembah ke bawah menyepak, sehingga menghasilkan loyalitas bawahan tanpa reserve.

Sedangkan birokrasi dan kultur struktur rasional-egaliter merupakan bentuk pemerintahan yang sering mengedepankan penghargaan pada fungsi nalar sehat dan manfaat hasil ilmu pengetahuan dan teknologi. Budaya yang dikembangkan di lingkungan birokrasi dengan pola ini berpotensi memberdayakan seluruh sumber daya manusia. Segala bentuk pelaksanaan kegiatan didasarkan pada kemaslahatan

Suhartono "Birokrasi, Kolusi dan Kriminalitas: Refleksi Historis" dalam Pidato Pengukuhan Jabatan Guru Besar Pada Fakultas Sastra UGM, (Yogyakarta: UGM Press, 2000), hal. 424. 
masyarakat yang harus ditetapkan segera tanpa harus menunggu-nunggu setelah munculnya bencana alam atau tuntutan masyarakat. Para pelaksana lembaga birokrasi memiliki kebebasan melaksanakan cara-cara baru yang praktis untuk pelayanan publik baik dengan inisiatif, antisipatif dan proaktif serta cerdas dalam membaca keadaan kebutuhan publik. Dalam konteks birokrasi berkultur dan secara struktur rasional-egaliter ini, semua orang sederajat di muka hukum dan menghargai prinsip kesederajatan kemanusian. Setiap orang yang berurusan dengan lembaga birokrasi diperlakukan dengan sama pentingnya.

Jika dalam sistem pemerintahan dengan pola birokrasi dan kultur struktur irasional-hirarkis yang dikedepankan, maka untuk penciptaan tata pemerintahan yang baik akan mengalami hambatan. Pola pemerintahan yang ini yang sering dikatagorikan sebagai bentuk sistem pemerintahan feodalistik. Alasannya sederhana sekali, dalam sebuah sistem pemerintahan yang terdiri dari kompleksitas budaya, tidak bisa hanya direduksi dengan kepentingan pelayanan kepada atasan. Bentuk loyalitas dapat dicabut jika bawahan tidak memenuhi seluruh perintah atasan. Dengan kata lain, bawahan harus pindah atau meninggalkan ruangan dan menjalani tugas keterasingan di tempat kerja yang baru. Sistem pemerintahan feodalistik ini akan menimbulkan dampak yang kurang baik, yaitu bekerja dengan tidak didasarkan pada asas profesionalitas. Sistem pemerintahan feodalistik lebih memperhatikan prinsip "asal bapak suka".

Dengan didasarkan pada bentuk birokrasi yang feodalistik ini, sangat mudah membuka peluang para pimpinan seenaknya menentukan arah kebijakannya. Besar kemungkinan, bentuk birokrasi seperti ini, akan menumbuhsuburkan pohon kolusi di benak hati para pemegang kebijakan. Suatu kenyataan, kolusi mempunyai motivasi yang kuat untuk mendapatkan keuntungan ekonomi dan politik para birokrat. Di kebanyakan negara berkembang, jaringan kolusi berkembang secara vertikal dan horisontal sehingga mudah memenuhi jaring-jaring kanker yang merata ke seluruh tubuh birokrasi. Akhirnya daya tahan sistem birokrasi pemerintah menjadi semakin lemah dan tidak mampu menghadapi pertumbuhan kolusi yang begitu cepatnya.

Kekuasaan birokrasi pemerintah yang sangat besar, ini menyebabkan sulit dikontrol oleh rakyat. Semua lembaga kontrol yang formal berada di birokrasi pemerintah dan tidak ada satu pun yang mau memberikan akses kepada rakyat untuk ikut mengontrolnya. Untuk memperbaiki sistem birokrasi yang seperti ini, tidak cukup hanya mendasarkan pada kontrol yang dilakukan sendiri, dari 
pemerintah, oleh pemerintah, dan untuk pemerintah. Pemerintah mengontrol birokrasi pemerintah. Itulah sebabnya korupsi jarang diberantas dan bahkan sangat subur, seperti yang terjadi pada zaman Orde Baru. ${ }^{6}$ Hal ini bisa saja menyebabkan suatu kesepakatan menyangkut pengaturan negara yang diciptakan bersama oleh pemerintah, masyarakat dan sektor swasta yang juga ikut berubah menjadi tali penghubung kejahatan besar yang dapat menindas, juga menyengsarakan masyarakat.

Birokrasi pemerintah di hampir negara berkembang hanya menjadi legitimasi para pemimpin yang sedang berkuasa. Tidak sedikit para pejabat selalu berpura-pura menjaga kepercayaan masyarakat, tetapi sebenarnya telah melakukan pembohongan kepada masyarakat secara luas. Terjadinya kolusi dalam sistem pemerintahan sudah tentu karena adanya kepentingan yang sama antara pemimpin pemerintah dan pemilik modal. Bertemunya pemimpin pemerintah dan pemilik modal merupakan korp kuat sebagai hasil kolusi yang dijalin dalam jalur birokrasi guna menciptakan loyalitas tunggal. Pada saat yang bersamaan, akan mudah ditemukan adanya seorang pemimpin lembaga pemerintah yang membantu rakyat, namun dengan cara yang salah, yakni meniru pola dan tata cara yang dilakukan oleh para penjajah.

Jika "loyalitas tunggal" dapat leluasa bergerak dan aman-aman saja, maka lain halnya cerita nasib rakyat yang terus mengalami konflik dan kesulitan memainkan peran-perannya. Demikian ini, jelas ada sebuah kesalahan dalam menerapkan prinsip good governance. Bukti adanya kesalahan ini, adalah masih adanya birokrasi pemerintah di satu sisi, namun di sisi yang lain, banyak penyimpangan yang merugikan negara dan masyarakat secara luas. Karenanya, perlu adanya upaya bersama untuk menciptakan kembali, meminjam bahasa T. Abdullah, "kondisi moral dan psikologis" yang essensial dalam bentukan demokrasi masa. ${ }^{7}$

Sistem birokrasi pemerintah merupakan ekspresi elit politik yang seharusnya tidak hanya mengedepankan"bentuk politik"8. Sistem pemerintahan tidak hanya terbatas pada persoalan administrasi yang efisien dan produktif,' tetapi juga pentingnya

6 Miftah Thoha, "Demokrasi Dalam Birokrasi Pemerintah Peran Kontrol Rakyat dan Netralitas Birokrasi” dalam Pidato Pengukuhan Guru Besar UGM Ilmu-ilmu Sosial, (Yogyakarta: UGM Press, 2000) hal. 1125.

7 Taufiq Abdullah, "Pengalaman, Kesadaran, dan Sejarah," dalam Pidato Pengukuhan Guru Besar UGM (Yogyakarta: UGM Press, 2000), hal. 380.

8 TIM LIP FISIP UI, Mengukur Sistem Politik Orde Baru, (Bandung: Mizan, 1998).

9 Rene Klaff, "Prinsip-prinsip Dasar Demokrasi dan Pemerintahan Yang Baik", dalam Islam dan Barat : Demokrasi dalam Masyarakat Islam, (Jakarta: Paramadina, 2002), hal. 107. 
mempertimbangkan prinsip etik dan standar moral yang digali dari keutamaan individu dan masyarakat. ${ }^{10}$ Prinsip etik dan standar moral seperti ini, yang dikatagorikan sebagai bentuk pemerintahan birokrasi berkultur dan berstruktur rasional-egaliter.

\section{Prinsip Moral dan Kesadaran Etis Good Governance}

Good governance merupakan istilah yang belakangan ini populer menyusul ketidakpuasan masyarakat di negara yang sedang berkembang. Terjadinya the paradox of development administration merupakan ironisme sistem pengelolaan sebuah tata pemerintahan. Terbentuknya pemerintahan yang baru dan secara umum dari katakatanya mudah diterka karena kata-kata itu berlawanan dengan arti poor governance, yaitu pemerintahan yang parah yang menunjuk pada pemerintahan lama yang penuh kecurangan.

Istilah ini dipopulerkan oleh UNDP dengan format: "Good governance is, among other things, participatory, transparent and accountable. It is also effective and equitable. And it promotes the rule of law. Good governance ensures that political, social and economic priorities are based on broad consensus in society and that the voices of the poorest and the most vulnerable are heard in decision-making over the allocation of development resources." 11 Dalam laporan Bank Dunia tahun 1997, masalah good governance ini menjadi bahan pembicaraan yang ramai dipersoalkan dengan mencakup hal-hal berikut: Predictable, open, and enlightened policy making, a bureaucracy imbued with a professional ethos acting in furtherance of public good, the rule of law, transparent processes, and a strong civil society participating in public affairs. Poor governance, on the other hand, is characterized by arbitary

10 Ubaidillah Achmad, "Pendidikan Multikulturalisme Gagasan Walisongo Menuju Keutamaan Individu dan Budaya Lokal," dalam Jurnal Terakriditasi Pendidikan Islam Universitas Islam Djakarta (UID), Vol. IX No. 2 Juli-Desember 2006, hal. 178 - 192.

11 Governance for Sustainable Development, UNDP, Januari 1997. Kendati diawali oleh badan-badan internasional dari dunia pertama (Eropa, Amerika Utara dan Jepang) melalui World Bank, UNDP, dan IMF tentang pentingnya good governance, namun demikian ini menjadi diskursus serius di negara-negara berkembang. Dalam diskurus ini, telah mendorong Lembaga Administrasi Negara (LAN) pemerintah Indonesia, dengan membrikan kesimpulan mengenai aspek fundamental dalam perwujudan good governance: Partisipasi (participation), penegakan bukum (rule of law), transparansi (transparancy), responsif (responciveness), orientasi kesepakatan (consensus orientation), keadilan (equity), efektivitas (effectiveness) dan efesiensi (efficiency), akuntabilitas (accountability), visi strategis (strategic vision). Dede Rosyada, et., el., Pendidikan Kewargaan: Demokrasi, HAM, Masyarakat Madani, (Jakarta: Kencana, 2000), hal. 182. 
policy making, unaccountable bureaucracies, unenforced or unjust legal systems, the abuse of executive power, a civil society engaged in public life, and widespread corruption. Good governance fosters strong state capable of sustained economic and social development and institutional growth. Poor governance undermines all efforts to improve policy making and to create durable institutions.

Pengertian good governance di atas, mencakup pemerintahan bersih, yang mencakup pertanggungan jawab secara jujur, transparan, diberlakukannya hukum dengan adil, visioner, responsif, akuntabel, profesional, efisien dan efektif, desentralisasi, demokratis dan berorientasi pada konsensus, partisipatif, kemitraan, supremasi hukum, pengurangan kesenjangan, komitmen pada pasar, komitmen pada lingkungan hidup, terciptanya kekuatan masyarakat sipil, hasil kebijakan yang terarah dan dapat diprediksi, pembangunan sosial ekonomi, pertumbuhan kelembagaan yang berkelanjutan, dan tertuju pada kebaikan masyarakat banyak. Oleh karena itu, kebijakan yang tidak berkelanjutan merupakan kendala pembangunan yang baik dalam sebuah sistem pemerintahan.

Namun demikian, kunci utama menuju keberhasilan governance tetap tergantung pada perilaku mental seperti peningkatan kesadaran, wisdom, komitmen, dan rasa tanggungjawab. Hal itu harus dilaksanakan secara baik (good). Good governance tidak akan berjalan efektif dan efesien, apabila tidak seimbang dengan sistem kontrol rakyat. Dasar argumentasi ini menegaskan, bahwa sistem politik dan sistem pemerintahan yang demokratis itu terletak pada wujud kontrol terhadap kegiatan pemerintah yang harus dilakukan oleh rakyatnya (control of government by the governed)..$^{12}$ Miftah Thoha mengakui, bahwa dalam masyarakat demokratis yang kompleks hampir tidak memungkinkan masyarakat melakukan kontrol dengan sempurna. Akan tetapi masyarakat bisa menaruh suatu harapan yang minim sekali pun dengan mengetengahkan suatu cara pemilihan (election) yang dilakukan oleh rakyat terhadap pejabat pemerintah. ${ }^{13}$

Meskipun sudah jelas dan mudah menentukan pilihan apakah sistem pemerintahan akan menerapkan birokrasi berkultur dan struktur rasional-egaliter atau birokrasi berkultur dan struktur irasional-hirarkis, namun prakteknya seringkali mereka yang sedang berkuasa menerapkan standar ganda dalam sistem pemerintahan. Contoh, adanya wujud rasionalitas dalam birokrasi yang masih

12 Baca, Judith Gruber, Controlling Bureaucracies, Dilemmas in Democratic Governance, (Los Angeles: University California Press, 1987).

13 Miftah Thoha, Demokrasi dalam Birokrasi...., hal. 1121 
ditengarahi oleh sistem yang menekankan pada hierarki kekuasaan (bierarchy of power). Sering kali, persepsi dan praktika birokrasi menganggap bahwa hierarki yang berada di atas mempunyai kekuasaan yang lebih besar dan hierarki di bawah mempunyai kekuasaan yang lebih kecil.

Sedangkan yang berada di luar hierarki (beyond the hierarchy) yang diduduki oleh rakyat atau masyarakat dianggap tidak mempunyai kekuasaan. Hal ini berarti jika rakyat menghadapi birokrasi, mereka tidak akan berdaya dan bisa diberdaya olehnya. Anggapan hubungan kekuasaan yang tidak seimbang ini, jelas akan memperlemah demokrasi dan cenderung menjadi alat dominasi - an instrument of domination - dari pejabat atasan terhadap pejabat di bawahnya, atau dari pejabat birokrasi terhadap rakyat. Persepsi birokrasi irasional-hirarkis seperti inilah yang membimbangkan pemikiran untuk menamakan birokrasi pemerintah itu bisa berlaku demokratis. ${ }^{14}$

Kondisi real sistem birokrasi pemerintah tetap membutuhkan respon dari masyarakat. Sebab, jika masyarakat tidak memaksa melakukan kontrol terhadap semua pelaksanaan birokrasi pemerintah, maka dapat dipastikan akan banyak terjadi penyimpangan kekuasaan. Dampak penyimpangan ini, akan membawa kerugian yang dialami oleh masyarakat lebih besar lagi dibandingkan dengan setelah adanya kontrol masyarakat terhadap pemerintah. Tugas aparatur negara dalam mensejahterakan masyarakat adalah memberdayakan (empowernment) seluruh potensi masyarakat. Upaya pemberdayaan masyarakat tersebut memerlukan prinsip semangat aparatur negara untuk melayani (a spirit to serve public) dan menjadi mitra ideal masyarakat (partner of society) atau dengan kata lain kerjasama sinergis dengan masyarakat dan swasta, untuk membangun bangsa dan pencapaian kesejahteraan sosial.

Good governance dalam birokrasi pemerintah membutuhkan kesadaran etis dan moral seluruh komponen masyarakat dalam membangun kesetaraan antara lembaga-lembaga negara baik di tingkat pusat maupun daerah, sektor swasta, dan civil society. Good governance yang berdasar pandangan ini berarti suatu kesepakatan pengaturan negara yang diciptakan bersama oleh pemerintah, civil socity dan sektor swasta. Kesepakatan tersebut mencakup keseluruhan bentuk mekanisme, proses dan lembaga-lembaga dimana warga dan kelompok masyarakat mengutarakan kepentingannya, menggunakan hak hukum, memenuhi kewajiban dan menjembatani perbedaan di antara mereka. ${ }^{15}$

14 Ibid., hal. 1122.

15 TIM ICCE Universitas Islam Negeri Syarif Hidayatullah, Demokrasi, HAM dan Masyarakat madani, (Jakarta: Kencana, 2000), hal. 181. 
Birokrasi pemerintah merupakan organisasi besar masyarakat, sehingga sistem birokrasi pemerintah harus disesuaikan dengan kebutuhan kultur lokal. Soedjito Sosrodihardjo menegaskan, bahwa setiap masyarakat mempunyai nilai-nilai sosial yang mengatur masyarakat tersebut. Termasuk di dalam nilai-nilai sosial ini adalah tata susila serta adat kebiasaan. Nilai sosial merupakan ukuran menilai tindakan dalam hubungannya dengan orang lain. Dengan nilai-nilai sosial ini orang yang satu dapat memperhitungkan apa yang akan dilakukan oleh orang lain. Maka, jika ada pertemuan antara anggota-anggota masyarakat yang berbeda nilai-nilai sosialnya, kerap kali mereka tidak dapat saling memperhitungkan tindakan-tindakan yang akan dilakukan oleh pihak lain. Demikian pula jika tidak ada keseragaman penilaian di dalam suatu masyarakat, maka akan berdampak saling memunculkan kecurigaan antara anggota masyarakat. ${ }^{16}$

Sehubungan dengan itu, penyebab utama terjadinya problem "the paradox of development administration" dalam penerapan good governance adalah karena menguatnya birokrasi pemerintah yang imbang dengan melemahnya kekuatan politik masyarakat maupun lembaga-lembaga politik. Dalam konteks ini, birokrasi pemerintah sebagai organisasi besar dalam sebuah masyarakat, tidak mampu mengakomodir pola adaptasi masyarakat, tujuan yang akan dicapai masyarakat, integrasi anggota-anggota masyarakat, dan kekuatan masyarakat dalam mempertahankan identitasnya dari ancaman internal maupun eksternal.

Oleh karena itu, meskipun pemerintah telah menerapkan tertib administrasi, efisiensi dan produktifitas, selama masih mengabaikan prasyarat fungsional sistem sosial hubungannya dengan individu dan masyarakat, ${ }^{17}$ maka akan terjadi perubahan yang merusak seluruh sistem yang sudah berlangsung dengan baik. Tidak heran, jika komitmen pelaksanaan good governance tetap melahirkan "the paradox of development administration." Untuk itu, dalam pelaksanaan good governance, perlu diiringi dengan adanya jaminan pada sistem sosial yang mendukung, kondisi ekonomi makro dan sosial politik yang kondusif, kebijakan program capacity building dengan memberdayakan yang kurang mampu, bersihnya pemerintah dari KKN, pemerintah yang public service, profesional, restrukturisasi sektor perbankan,

16 Soedjito Sosrodihardjo, "Nilai-nilai Sosial dan Perubahan Struktur Masyarakat," dalam Pidato Pengukuhan Jabatan Guru Besar Pada Fakultas Sosial dan Politik UGM, (Yogyakarta: UGM Press, 2000), hal. 29.

17 K.J. Veeger, "Realitas Sosial: Refleksi Filsafat Sosial atas Hubungan Individu-Masyarakat" dalam Cakrawala Sejarah Sosiologi, (Jakarta: Gramedia, 1993). 
restrukturisasi hutang luar negeri/swasta, dan pemulihan sektor ril (perdagangan luar negeri, kebijaksanaan pangan nasional, deregulasi bidang investasi dan programprogram sosial dan pemberdayaan rakyat). ${ }^{18}$

Termasuk yang segera membutuhkan reformasi adalah model birokrasi yang berkembang sekarang ini. Model birokrasi Indonesia saat ini dapat dilihat dari bentuk bahasa yang digunakan, yakni bahasa kekuasaan. Pejabat birokrasi Indonesia hanya mengetahui satu bahasa yakni bahasa kekuasaan seperti; tangkap, subversif, bubarkan, gebuk, amankan, culik, ${ }^{19}$ laksanakan, lanjutkan, selesaikan, proses, dan kata sejenis yang menunjukkan bahwa pejabatlah yang paling benar sendiri. Selain bahasa kekuasaan tersebut, yang tidak relevan dari birokrasi dan kultur struktur rasionalegaliter, di antaranya; pertama, sentralisasi. Sentralisasi merupakan ciri administrasi publik negara yang otoritarian. Kedua, loyalitas tunggal antara birokrat, politisi dan pengusaha merupakan ciri birokrasi pemerintah yang belum berpihak kepada masyarakat, sehingga apapun yang dilakukan tidak ada tujuan lain kecuali untuk memerintah (apparently they do just about everything but govern) ${ }^{20}$. Demikian ini akan menghambat upaya-upaya yang menekankan netralisasi birokrasi pemerintah. Beberapa model itu adalah perwakilan konstitusional (constitutional / representative government); perhitungan pluralis (pluralist/account); dan otonomi yang demokratis (the autonomy of the democracy model). ${ }^{21}$

Netralitas birokrasi pemerintah ini mempunyai cara sendiri-sendiri sebagaimana harusnya pilar sentral dari suatu pemerintahan, yakni pegawai pemerintah (the civil service) harus bekerja melaksanakan tugas dan tanggung jawabnya, apakah mereka itu memihak atau netral dalam hubungannya dengan kekuatan politik yang ada. Model ini dikatakan oleh Hussel sebagai "natural attitude", dan Schultz. Natural attitude ini sering disebut "lebenswelt" atau "everyday life world".Demikian ini dapat dijadikan solusi untuk menindaklanjuti kebijaksanaan pemerintah tentang netralisasi pegawai negeri dari parpol. Netralitas di sini mempunyai makna bahwa pegawai pemerintah berkeinginan dan harus mampu melayani secara sama (equal effectiveness) kepada perbedaan administrasi yang datang silih berganti. ${ }^{22}$

18 Haryoso, Pembaruan Birokrasi dan Kebijaksanaan Publik, (Jakarta: Peradaban, 2002), hal. 193-194.

19 Miftah Thoha, Demokrasi dalam Birokrasi..., hal. 1127.

20 Ibid. hal. 1132.

21 Ibid. hal. 1134.

22 Ibid. hal. 1134. 
Setiap pejabat tidak dapat melepaskan diri dari prinsip moral dan standar etika yang berlangsung dalam perkembangan sistem sosial. Dengan memperlakukan individu yang lain, sama artinya memperlakukan dirinya sendiri sebagai manusia yang memiliki nilai-nilai intrinsik. Individu itu, menurut Immanuel Kant bernilai dalam diri sendiri. ${ }^{23}$ Karena itu, tiap penguasaan atau perbuatan yang mengintervensi individu adalah merupakan pelanggaran atas norma moral. Jika seseorang yang berkuasa mementingkan kepentingannya sendiri, sementara individu yang lain yang menjadi tanggungjawabnya tersiksa, berarti telah melakukan pelanggaran terhadap dirinya sendiri.

Birokrat pemerintah harus memberikan pemahaman dan penghargaan yang baik kepada individu. Ini penting, sebab jika pemahaman dan penghargaan birokrat pemerintah pada individu lemah, maka akan sangat mudah melahirkan potensi agresif tiap-tiap individu dalam masyarakat yang dipimpin. Karena itu, standar etika dan prinsip moral seorang pemimpin menjadi pedoman saat muncul kepentingan dalam intern kekuasaan itu sendiri. Sebab, jika kepentingan seorang pemimpin sejalan dengan standard etika dan prinsip moral masyarakat umum, maka kepentingan masyarakat umum akan tetap terjamin melalui pelayanan profesional itu. Namun sebaliknya, jika standar etika dan prinsip moral ini diabaikan oleh para birokratnya, maka birokrasi pemerintah akan menjadi sasaran kemarahan masyarakat.

Tugas mengelola birokrasi pemerintah merupakan hak istimewa para pejabat. Ketika tugas ini diserahkan kepada para pejabat yang tidak memiliki tanggungjawab terhadap moral dan etika, maka rakyat akan menjadi pihak yang selalu dirugikan. Kerugian rakyat ini akan lebih diperparah dengan kehadiran para politisi dan pengusaha. Pejabat, politisi dan pengusaha yang masuk ke lembaga pemerintahan tidaklah bersih dari kepentingan. Akibatnya, masyarakat harus menanggung resiko bagaimana para pejabat, politisi dan pengusaha memainkan lembaga pemerintahan. Logika sederhananya adalah, jika anggaran awal diperlukan oleh unit lembaga pemerintahan demi terlaksananya program kegiatan, unit lembaga pemerintah cukup meminta pinjaman dari pengusaha yang masuk ke lembaga pemerintah.

Berhubungan dengan kelompok kepentingan merupakan resiko birokrat yang akan berdampak langsung pada sistem pemerintahan. Keterpurukan birokrasi pemerintah, tidak dapat dilepaskan dari watak Individu yang dijadikan pemimpin

23 Dalil Kant ini, dapat dibaca pada bukunya, Immanuel Kant, Critique of Practical Reason, Terj. Nurhadi, (Yogyakarta: Pustaka Pelajar, 2005). 
birokrasi pemerintah. ${ }^{24}$ Watak yang baik dari seorang pemimpin merupakan keniscayaan yang tidak dapat diabaikan dalam menentukan kepemimpinan di birokrasi pemerintah. Jika pemimpin eksekutif tertinggi menggadaikan etika jabatannya dan standar moral, tidak ada lagi yang dapat mempertahankan good governance. Sadar akan campur tangan berbagai kepentingn politis dan bisnis yang memperburuk birokrasi pemerintah, maka dibutuhkan pengawasan dari berbagai pihak, baik berupa pengawasan adiministratif maupun substantif. Dalam konteks ini, agama dapat turut berperan mengisi nilai-nilai ajarannya di tengah berlangsungnya sistem pemerintahan. Namun demikian, peran agama akan berimplikasi pada hal-hal yang tidak baik apabila cendekiawan agama turut mengusung faktor ideologis tanpa mempertimbangkan kepentingan yang lebih luas lagi. Peran cendekiawan agama adalah sebagai pendamping dalam pertumbuhan dan pemberdayaan (empowerment) masyarakat relasinya dengan kekuasaan pemerintah.

Cendekiawan agama bisa mengambil pengalaman negara barat yang sudah maju, ${ }^{25}$ yang kemudian dapat disesuaikan dengan kebutuhan lokal. Pengalaman ini dapat diarahkan untuk mewujudkan wilayah publik yang bebas (a free public sphere); melakukan kontrol atas sistem pemerintahan yang sedang berlangsung; melakukan kritik atas sistem dan budaya yang mendukung rezim totaliter; mencari alternatif baru bagi masyarakat yang menjadi korban birokrasi pemerintah; dan mampu menghindarkan diri dari kelemahan-kelemahan dasar sistem demokrasi liberal kapitalis dan sosialis komunistis yang tidak sesuai dengan budaya lokal.

\section{Penguatan Struktur Rasional-Egaliter}

Jika masyarakat beragama memahami keutamaan nilai agama yang berfungsi untuk pembinaan individu dan sistem sosial, maka nilai-nilai agama akan sangat dapat dirasakan perannya di tengah hubungan antara individu, sistem sosial dan birokrasi pemerintah. Namun yang terjadi justru sebaliknya, nilai-nilai agama tidak nampak sebagai sebuah ajaran moral yang sangat tinggi. Umat beragama lebih memahami ajaran agama sebagai simbol komunal dan legitimasi pendorong

24 Istilah watak ini, penulis ambil dari pemaknaan antropologis S. Takdir Alisjahbana, Antropologi Baru: Nilai-nilai Sebagai Tenaga Integrasi dalam Pribadi, Masyarakat dan Kebudayaan, (Jakarta: Dian Rakyat, 1986), hal. 69 - 70.

25 Muhammad AS Hikam, Demokrasi dan Civil Society, (Jakarta: LP3ES, 1999), hal. 199. 
terjadinya konflik antara individu, sistem sosial dan birokrasi pemerintah. Masih selalu segar dalam ingatan umat beragama, sejak munculnya konsep negara bangsa, agama diterjemahkan para pengikutnya untuk selalu menjaga komunalitas keberagamaan. Implikasi yang dapat disaksikan, keberadaan umat beragama di birokrasi pemerintah justru menjadikan birokrasi pemerintah sebagai sarang korupsi, kolusi dan nepotisme. ${ }^{26}$

Demikian ini berbeda dengan nilai-nilai yang ditekankan dalam ajaran agama, bahwa agama merupakan rumusan kepercayaan, dogma, keimanan yang dapat diaplikasikan dan dioperasionalkan dalam keanekaragaman realitas sosial. Konsepsi mengenai agama seharusnya diletakkan sebagai sumber membangun tatanan sosial, sumber etika dan moral dalam kehidupan bermasyarakat. Bangunan agama seperti ini paralel dengan program pemberdayaan yang pernah dilakukan nabi Muhammad yaitu menciptakan masyarakat yang berpegang pada prinsip moral dan etika serta membangun birokrasi dan kultur struktur rasional-egaliter.

Akibat agama yang tidak dipahami sebagai sumber nilai ini, maka yang berkembang dalam aktifitas keberagamaan adalah selalu mengatasnamakan agama dalam tindakan amoralnya. Tipe keberagamaan ini, dalam realitas sosial mewarnai ketegangan antar sesama umat beragama dan agama dalam hubungannya dengan negara. Jika komunalisme agama berkembang tanpa berkesudahan, maka peran agama sebagai "way of life" tidak akan berarti dalam sistem sosial. Agama hanya dijadikan sebagai media untuk memberikan harapan akan adanya kehidupan yang abadi dan legitimasi politis memperebutkan kekuasaan lembaga pemerintahan.

Jika prinsip moral dan etika agama dilupakan di tengah penataan sistem pemerintahan, maka dapat dipastikan akan terjadi distorsi dalam memaknai agama. Terjadinya distorsi memaknai agama seperti inilah yang tidak disadari telah merusak citra agama. Oleh karena itu, agama perlu dikembalikan pada perannya semula, yakni sumber etika dan moral kehidupan manusia. ${ }^{27}$ Prinsip moral dan etika agama dapat mendukung orientasi hidup yang positif, dinamis dan progresif: orientasi pada perbuatan (action oriented); orientasi pada kualitas (quality oriented); orientasi

26 Arbi Sanit, ets., Korupsi Di Negeri Kaum Beragama: Ikbtiar Membangun Fiqh Anti Korupsi, (Jakarta: P3M, 2004).

27 Abdurrahman Wahid, "Republik Bumi di Sorga," dalam Prisma Pemikiran Gus Dur 19751984, (Jakarta: LP3ES, 1985), hal. 265; Philipus Tule, "Nuansa Dasariah Buku Islamku Islam Anda Islam Kita: Sebuah Tinjauan Teologis, Sosiologis dan Antropologis, "Makalah Acara Bedab Buku, berjudul ISLAMKU ISLAM ANDA ISLAM KITA, di Jakarta pada tanggal 26 Maret 2007. 
pada tujuan (goal oriented); dan orientasi pada masa depan (future oriented); mengajarkan agar berpegang pada prinsip keadilan (al-'adalab); persaudaraan (alukhuwwah); permusyawaratan (al-syura); persamaan (al-musyawwab); dan menghargai kemajemukan (al-ta'addudiyyah) serta lebih mendahulukan perdamaian daripada peperangan.

Untuk menghindari benturan nilai kesenjangan antara ajaran agama dan good governance, perlu kiranya menegaskan relevansi nilai-nilai agama dengan sistem pemerintahan. Prinsip nilai agama dapat mendukung keutamaan sistem pemerintahan yang telah dikelola dengan baik. Oleh karena itu, dalam aktifitas keberagamaan, apabila mengabaikan nilai agama, maka ajaran agama tidak akan dapat berfungsi mengatur relasi positif antara agama dan good governance. Sebab, prinsip good governance tidak dapat memastikan harapan ideal tanpa adanya kesadaran nilai agama dari masyarakatnya. Jika demikian kenyataannya, nilai-nilai ajaran agama dapat dijadikan sebagai sumber keutamaan sejarah, agar umat lebih memperhatikan good governance dalam menjalankan kehidupan berbangsa dan bernegara. Dengan kata lain, umat beragama tidak boleh mengabaikan kehidupan dunia, termasuk mengabaikan tindakan sewenang-wenang dari para pemimpin lembaga pemerintahan. Sebab, jika lembaga pemerintah tidak dalam pengawasan masyarakat, maka hanya akan memperkokoh bangunan hegemoni kekuasaan.

Secara spesifik, ajaran agama memiliki kesamaan dengan sistem pemerintahan yang baik yang juga sama-sama berorientasi pada kesejahteraan masyarakat. Contoh, agama dan good governance sama-sama menjamin sistem pemerintahan yang baik, menjamin kondisi perekonomian masyarakat dan sosial politik yang saling memberikan perlindungan, menjaga kebijakan dan program capacity building dengan memberdayakan yang kurang mampu, menjaga pemerintahan yang bertanggung jawab, mempertahankan bersihnya pemerintah dari KKN, menciptakan pemerintahan yang public service, profesional, restrukturisasi sektor simpan-pinjam, restrukturisasi hutang-piutang, mendukung kebijakan pangan masyarakat, deregulasi di bidang investasi dan program pemberdayaan rakyat. Dengan kata lain, agama menekankan nilai-nilai dalam sistem pemerintahan, sedangkan good governance, menekan agar pelaksanaan lembaga pemerintahan di bangun atas dasar sistem yang baik, yakni sistem yang memihak pada kepentingan masyarakat luas.

Oleh karena itu, meskipun lembaga agama, politik berbasis agama, dan komunalitas keagamaan lainnya semarak di tengah sistem pemerintahan, selama belum memenuhi prinsip spesifik tersebut, maka dikatagorikan telah mengabaikan 
nilai-nilai ajaran agama yang sebenarnya. Sistem pemerintahan pun tidak boleh disilaukan dengan gerakan-gerakan yang mengatasnamakan agama. Mengapa nilainilai agama yang harus disintesakan dengan good governance? Karena sistem pemerintahan itu bertanggung jawab pada semua masyarakat. Sehingga menjadi agenda umat beragama untuk mendampingi dan memperkuat bangunan sistem yang memihak kepentingan masyarakat. Ibarat sistem alam, jika agama berubah dari prasyarat fungsional yang telah ditentukan, maka akan merusak seluruh bangunan sosial yang sudah berlangsung dengan baik di tengah kebersamaan dengan berbagai ragam budaya masyarakat yang menyertai model diterapkannya sistem pemerintahan. Karenannya, sistem pemerintahan sudah seharusnya dapat menjadi alternatif sistem yang dapat merangkum tata nilai masyarakat yang beragam dan sudah berlangsung berabad-abad lamanya.

Adapun fungsi agama adalah untuk menguatkan birokrasi berkultur struktur rasional-egaliter. Tidak saatnya lagi memperdebatkan bagaimana umat beragama membela agamanya, tetapi logika beragama yang benar adalah, bagaimana ajaran agama dapat berperan di tengah sistem yang dibangun oleh masyarakat sesuai dengan nilai-nilai yang diajarkan dalam kitab suci. Setiap penguasa, raja, presiden, gubernur, bupati, camat, dan kepala desa, dapat menjadikan sumber keutamaan nilai-nilai agama. Dengan memperlakukan individu atau pribadi dalam kerangka tujuan ke arah good governance, sama artinya melaksanakan tuntunan agama. Individu itu bernilai dalam ajaran agama. Karena itu, umat beragama harus melindungi otonomi individu, umat beragama harus menjadi sarana perbaikan bagi tujuan individu dan masyarakat. Jelas, meskipun ada sebagian umat beragama mengatasnamakan agamanya, selama masih mementingkan kepentingan golongannya sendiri, merupakan pelanggaran yang besar yang tidak bisa dimaklumi oleh nilai-nilai ajaran agama.

Dalam konteks inilah, agama dan good governance menjadi senyawa dalam kehidupan masyarakat modern. Nilai-nilai ajaran agama dan sistem pemerintahan yang baik, sama-sama ingin menjaga kepentingan masyarakat umum melalui pelayanan profesional; tidak ingin memanfaatkan sistem kekuasaan menjadi sebuah perusahaan pribadi; menolak negosiasi dan terjadinya politik dagang sapi; mengorbankan martabat pejabat, memperalat para pelaksana pemerintah, mengelabuhi kebijakan, dan menipu masyarakat; menghormati pribadi atau yang lain sebagai bernilai dalam diri sendiri; serta tidak memanfaatkan masyarakat sebagai alat demi tujuan legitimasi kekuasaannya. 
Untuk itulah dalam nilai-nilai ajaran agama dan sistem pemerintahan samasama dapat dijadikan dasar menata martabat standar moral pejabat publik. Praksis keterlibatan nilai-nilai ajaran agama dan sistem pemerintahan juga mengajarkan asas proporsionalitas dan menegaskan, bahwa para pemimpin itu akan dimintai pertanggungjawaban agar kepemimpinannya tetap menjaga martabat dan harkat seluruh umat manusia. Oleh karena itu, tidak diperkenankan para pemimpin hanya bisa menjaga martabatnya dan harkatnya sendiri. Tanggung jawab para pemimpin paling berharga dalam ajaran agama dan sistem pemerintahan yang baik.

Nilai-nilai ajaran agama dan sistem pemerintahan yang baik dapat berperan mendukung pemberdayaan (empowerment) pada masyarakat lokal; mewujudkan wilayah publik yang bebas (a free public sphere); melakukan kontrol atas sistem pemerintahan yang sedang berlangsung; melakukan kritik atas sistem dan budaya yang mendukung rezim totaliter; mencari alternatif baru bagi masyarakat yang menjadi korban sistem pemerintahan yang sedang berlangsung; dan mampu menghindarkan diri dari kelemahan-kelemahan dasar sistem demokrasi liberal kapitalis dan sosialis komunistis yang tidak sesuai dengan budaya lokal.

Untuk menanggulangi sistem pemerintahan yang tidak baik, peranan agama tidak bisa diabaikan. Demikian ini sejalan dengan prasyarat sistem pemerintahan yang diajarkan agama. Firman Allah: Innallâh ya-murukum antu-addû al-amanât

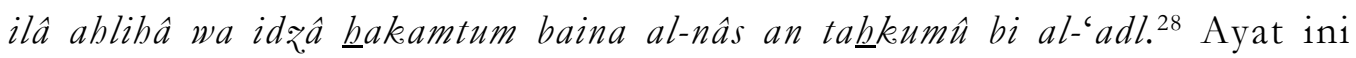
menekankan agar semua pemimpin melaksanakan amanahnya dan bersikap adil dalam kepemimpinannya. Menanggapi ayat ini, terkait dengan arti pentingnya seorang penguasa pemerintahan dalam kehidupan masyarakat luas, meminjam Istilah Ibn Khaldun, dalam sistem pemerintahan yang sesuai dengan nilai-nilai agama tidak hanya berorientasi pada hablum minallâh, tetapi juga sistem pemerintahan yang menggunakan norma-norma politik hasil rasio yang didasarkan pada bablum minannâs. ${ }^{29}$ Artinya, yang dimaksud dengan norma politik hasil rasio, adalah norma politik yang didasarkan pada kontrak-kontrak sosial dan budaya lokal.

Qawaid al-Figh, sebuah kaidah hukum Islam yang hingga sekarang masih selalu dijadikan dasar para pemikir muslim, lebih tegas lagi dalam meletakkan hakikat sebuah kekuasaan: Tasharruf al-imâm 'alâ al-raiyyah manûth bi al-mashla $\underline{h} a b$ ". Artinya, seluruh kebijakan dan tindakan pemimpin terhadap rakyat haruslah selalu

28 QS. An-Nisa: 59.

29 Abd. Rahman Ibnu Khaldun, Muqaddimah, (Beirut: Dar al-Fikr, 1969), hal. 190. 
bersumber pada kemaslakhatan masyarakat luas. Sehubungan dengan implikasi kebijakan dan tindakan pemimpin ini telah digambarkan oleh Ibn Khaldun dengan sangat elok, yaitu apabila negara menjauhi ketidakadilan, tipu daya, kecurangan, menjaga berlakunya sistem yang benar serta tidak membelokkannya, maka di pasarnya akan laku barang-barang sejenis perak dan emas murni. Namun apabila negara dipengaruhi oleh kepentingan pribadi, persaingan yang tidak sehat, atau dipenuhi oleh kelaliman, tirani dan ketidakjujuran, maka yang laku di pasarnya hanyalah barang-barang yang tak berharga dan benda-benda logam yang tak bernilai. ${ }^{30}$

Kritik dan koreksi terhadap sistem pemerintahan yang harus dipertahankan merupakan ciri khas keberagamaan umat beragama. Dengan lain ungkapan, keterkaitan antara prinsip good governance dan etika agama, sebenarnya lebih mewarnai corak tradisi keberagamaan yang berkembang dalam realitas peradaban manusia. Upaya menyatukan bangunan good governance dengan etika agama merupakan problem mendasar yang tidak terlepas dari sejarah keberagamaan umat manusia.

Oleh karena itu, seiring dengan dibutuhkannya struktur rasional-egaliter di tengah kehidupan penganut agama-agama dewasa ini, manusia beragama pada umumnya selalu merespon terjadinya "musibah" yang selalu menimpa pengikut agama-agama, terutama dalam hubungannya dengan "kepentingan" politik, ekonomi dan sosial budaya. Karenannya, patut diajukan pertanyaan berikut; Kapan pengikut agama-agama menawarkan konsep penanggulangan sistem pemerintahan yang tidak baik? Jangan-jangan, para agamawan terutama tokoh-tokoh dan cendekiawan agama kurang begitu menaruh perhatian dan tidak begitu tanggap terhadap isu-isu good governance karena konsepsi keberagamaannya yang masih saja terfokus ke persoalan sorga yang langka. Di samping kurangnya motivasi dari faktor eksternal, juga karena adanya factor internal pengikut agama itu sendiri, dimana agama masih dipahami sebagai bahasa dogma yang belum aplikatif terkait dengan kehidupan berbangsa dan bernegara.

Jika konsep keberagamaan tidak memperlihatkan wujud nyata sikap dan karakter umat beragama, terus terang peran agama hanya sebagai konsep fiktif di tengah perkembangan ilmu pengetahuan dan teknologi. Penulis sendiri menemukan realitas yang terjadi di tengah sistem pemerintahan yang nota benenya di pimpin oleh mereka yang aktif dalam ritual keagamaan, namun yang terjadi justru

$30 \quad$ Ibid., hal. 440. 
berjalannya sebuah sistem yang tidak sesuai dengan prinsip good governance dan etika agama. ${ }^{31}$ Meskipun realita keberagamaan memanglah demikian, penulis masih menaruh keyakinan, bahwa nilai-nilai ajaran agama dapat dikembalikan perannya dalam tata pemerintahan.

Jika aktivitas keberagamaan umat beragama tidak mampu memecahkan problem struktur irasional-hirarkis, maka merupakan bentuk keberagamaan yang tidak sesuai dengan ajaran agama. Oleh karena itu, beragama harus mampu mempersiapkan pikiran menghadapi ancaman kekeliruan dan ilusi yang terusmenerus menjadi parasit dalam kehidupan manusia. Umat beragama harus memperjuangkan nilai ajaran agama yang aplikatif. Agama harus mampu menjawab berbagai disposisi psikologis dan budaya yang membuat masyarakat rentan terhadap kekeliruan dan ilusi. Tujuan beragama adalah penerusan atau penetapan nilai-nilai moral. Kegagalan umat beragama ini dapat dilihat pada kecenderungannya terhadap kekerasan dan ketidakadilan. Bentuk-bentuk penolakan terhadap struktur rasionalegaliter dan prinsip kebenaran etik yang lain, merupakan bentuk penyimpangan terhadap ajaran agama.

\section{E. Penutup}

Melihat yang demikian, salah satu peran yang masih dapat diharapkan dari agama adalah membuat umatnya insaf akan adanya suatu kekuasaan, yang melebihi segalagalanya dan sangat penting bagi keselamatannya. Tentang sifat dan hakikat kekuasaan dzat nan mutlak (ultimate reality) itu terdapat berbagai anggapan serta kepercayaan yang didasarkan pada kayakinan tiap agama. Agama mempengaruhi bentuk masyarakat dan sering dijadikan sumber moral, etika dan nilai sistem pemerintahan.

Dengan demikian, dalam aktifitas keberagamaan diperlukan kesadaran umatnya untuk mengarahkan gerak laju mekanisme pemerintahan yang semula destruktif-represif, ke arah tujuan yang lebih membebaskan dan mempotensikan rakyat miskin (dhu'afa', mustadh'afin). Lagi-lagi, di sini diperlukan semangat kaum agamawan menjadikan agama sebagai sumber pengakuan ide dan keyakinan yang dapat menyadarkan masyarakat tentang pentingnya keutamaan agama mendukung keutamaan good governance. Kerja keberagamaan untuk memperbaiki pemerintahan yang tidak baik, tampaknya belum pernah terpikirkan secara serius

31 Baca, A.S. Burhan, dkk (Edit.), Korupsi di Negari Kaum Beragama: Iktiar Membangun Fiqh Anti-Korupsi, (Jakarta: Partnership For Governance Reform in Indonesia, 2004). 
oleh umat beragama, kecuali dalam tataran retorika kecil. Kini pengaruh agama sebagai agama sangat kurang. Para pemeluk agama-agama besar pun mudah mengalah pada kebiasaan jelek seperti korupsi, kurang tanggungjawab di bidang administrasi, bisnis, perjanjian dan ikut menindas golongan lain.

Dalam realitasnya, umat beragama masih terlalu jauh menjadikan agama sebagai sumber energi untuk menumbuhkan sikap baik dan sehat dalam sebuah sistem pemerintahan. Karenanya, umat beragama perlu menghayati keutamaan prinsipprinsip agama yang terkait dengan komitmen pada perbaikan "kehidupan politis" yang lebih sehat, mendorong partisipasi, pemerkuatan sendi-sendi kehidupan demokratis, membangun sistem pemerintahan yang baik. Sudah sangat jelas dan tegas, bahwa agama merupakan kebenaran universal. Karenanya, penguatan struktur rasional egaliter, sama artinya melakukan penguatan terhadap nilai-nilai ajaran agama.

\section{DAFTAR PUSTAKA}

Abdullah, Taufiq. 2000. "Pengalaman, Kesadaran, dan Sejarah," dalam Pidato Pengukuhan Guru Besar UGM, Yogyakarta: UGM Press.

Abdurrahman Wahid. 1985. "Republik Bumi di Sorga," dalam Prisma Pemikiran Gus Dur 1975-1984, Jakarta: LP3ES.

Achmad, Ubaidillah. 2006. "Pendidikan Multikulturalisme Gagasan Walisongo Menuju Keutamaan Individu dan Budaya Lokal," dalam Jurnal Terakriditasi Pendidikan Islam Universitas Islam Djakarta (UID), Vol. IX No. 2 JuliDesember.

Alisjahbana S. Takdir. 1986. Antropologi Baru: Nilai-nilai Sebagai Tenaga Integrasi dalam Pribadi, Masyarakat dan Kebudayaan, Jakarta: Dian Rakyat.

Burhan, A.S., dkk (Edit.). 2004. Korupsi di Negari Kaum Beragama: Iktiar Membangun Fiqh Anti-Korupsi, Jakarta: Partnership For Governance Reform in Indonesia.

Effendi, Sofian. 2000. "Revitalisasi Sektor Publik Menghadapi Keterbukaan Ekonomi dan Demokratisasi Politik" dalam Pidato Pengukuban Jabatan Guru Besar Pada Ilmu Sosial dan Ilmu Politik UGM, Yogyakarta: UGM Press.

Gruber, Judith. 1987. Controlling Bureaucracies, Dilemmas in Democratic Governance, Los Angeles: University California Press. 
Haryoso. 2002. Pembaruan Birokrasi dan Kebijaksanaan Publik, Jakarta, Peradaban. Hikam, Muhammad A.S. 1999. Demokrasi dan Civil Society, Jakarta: LP3ES.

Kant, Immanuel. 2005. Critique of Practical Reason, Terj. Nurhadi, Yogyakarta: Pustaka Pelajar.

Khaldun, Abdurrahman Ibn. 1951. Muqaddimah, Bierut: Dar al-Fiqr

Klaff, Rene. 2002. "Prinsip-prinsip Dasar Demokrasi dan Pemerintahan Yang Baik" dalam Islam dan Barat: Demokrasi dalam Masyarakat Islam, Jakarta: Paramadina

Rosyada, Dede, et., el. 2000. Pendidikan Kewargaan: Demokrasi, HAM, Masyarakat Madani, Jakarta: Kencana.

Sanit, Arbi, ets. 2004. Korupsi Di Negeri Kaum Beragama: Ikbtiar Membangun Fiqh Anti Korupsi, Jakarta: P3M.

Sosrodihardjo, Soedjito. 2000. "Nilai-nilai Sosial dan Perubahan Struktur Masyarakat" dalam Pidato Pengukuban Jabatan Guru Besar Pada Fakultas Sosial dan Politik UGM, Yogyakarta: UGM Press.

Suhartono. 2000. "Birokrasi, Kolusi dan Kriminalitas: Refleksi Historis," dalam Pidato Pengukuhan Jabatan Guru Besar Pada Fakultas Sastra UGM, Yogyakarta: UGM Press.

Thoha, Miftah. 2000. "Demokrasi Dalam Birokrasi Pemerintah Peran Kontrol Rakyat dan Netralitas Birokrasi," dalam Pidato Pengukuban Guru Besar UGM Imu-ilmu Sosial, Yogyakarta: UGM Press.

TIM ICCE Universitas Islam Negeri Syarif Hidayatullah. 2000. Demokrasi, HAM dan Masyarakat madani, Jakarta: Kencana.

TIM LIP FISIP UI. 1998. Mengukur Sistem Politik Orde Baru, Bandung: Mizan.

Tule, Philipus. 2007. 'Nuansa Dasariah Buku Islamku Islam Anda Islam Kita: Sebuah Tinjauan Teologis, Sosiologis dan Antropologis," Makalah Acara Bedah Buku, berjudul ISL AMKU ISL AM ANDA ISL AM KITA, di Jakarta pada tanggal 26 Maret.

Veeger, K.J. 1993. Realitas Sosial: Refleksi Filsafat Sosial atas Hubungan IndividuMasyarakat dalam Cakrawala Sejarah Sosiologi, Jakarta: Gramedia.

Website Masyarakat transparansi Indonesia. 2000. Masalah Birokrasi di Indonesia, Jurnal Transparansi. Edisi 18 Maret. 